\title{
The Scrutinized Priest: Women in the Church of England Negotiating Professional and Sacred Clothing Regimes
}

This article examines the integration of women priests in the Church of England through the lens of dress. Clothing is a salient dynamic in occupational cultures, particularly in relation to the regulation of gendered bodies. Women's ordination to the priesthood was only sanctioned in 1992. Complex clothing regimes are negotiated, for ordination bestows upon the priest certain clothing rights and responsibilities. However, such attire has traditionally been associated only with the male body, creating tension in relation to women's appropriation of this sacred and professional dress. Based on in-depth interviews with 17 Anglican clergy women, this article will focus both on the scrutiny the women experienced in relation to their clothing choices, as well as the relationship the women themselves negotiated with their clothes. It will be argued that as representatives of both a sacred and professional domain, clothing had to be carefully managed by clergy. Dress functioned as a key test in women's integration into the organization, often operating as a constraining and exclusionary mechanism.

Keywords: clothing, Church of England, gender, women priests

\section{Introduction}

The Church of England voted to allow women's ordination to priesthood in 1992. By 2010 women made up 22.2 per cent of stipendiary (paid) clergy; meanwhile, of those ordained in 2010, 51.5 per cent were women (Church of England, 2011). StewartThomas (2010) has articulated how religious organizations can be fruitful case studies for understanding how organizations become gendered, especially because many have only allowed women access to official leadership positions very recently, and women have quickly emerged as key contributors to ordained roles. This period of rapid change demonstrates the impact on gender dynamics in organizations that have historically been constituted not only as masculine, but sacredly masculine (Bock, 
1967). These changes have also taken place in a context where women's equality is not necessarily endorsed. Unlike secular organizations which are automatically compelled to subscribe to gender equality legislation, religious organizations remain exempt within UK law. The most recent high-profile manifestation of this occurred in November 2012, when the Church’s legislative body, the General Synod, rejected the legislation which would have allowed women's appointment as bishops. This event proved extremely newsworthy - the BBC carried a live internet news feed as the vote progressed, and a number of newspapers put the story on their front page. This highlights the continuing interest this debate generates even for a largely nonchurchgoing population, especially when the debate is pitched in terms of church traditionalism versus egalitarian norms. Therefore, in the context of the Church of England, it seems paradoxical that higher numbers of women are being ordained within an institution where gender egalitarianism - something non-negotiable in most secular institutions - is not legally endorsed.

The controversies over women's position in the Church are nothing new. The vote to allow women's ordination to priesthood in 1992 was preceded by great contestation. The debate had intensified over the course of the 1980s (Dowell and Williams, 1994; Gill, 1994; Webster, 1994), and those within the Church were extremely divided over resolving the issue. Campaign groups on both sides were active, with debates emerging over whether women's priesthood complied with tradition, whether a woman could represent Christ, and whether the Bible prohibited women's priesthood on the grounds of headship (i.e. whether it is biblically permissible for women to be in positions of authority over men). Meanwhile those arguing for women's priesthood did so on the grounds of inclusion and equality, the presence of women priests in the early Church, and whether maleness was an essential requirement for representing Christ (Dowell and Williams, 1994). Once the vote affirming women's priesthood was passed in 1992, the reaction of bishops and clergy was sombre, with those in favour instead being sustained by positive news coverage and the overwhelming support from the general public (Furlong, 1998). Even here, though, sexist overtones remained. The Sun's headline - 'The Church Says Yes to Vicars in Knickers' - sexualized and trivialized the issue (Walsh, 2000). Meanwhile in the churches, some parishioners remained extremely ambivalent, with a minority refusing to accept communion from a woman (Blohm, 2005; Dyer, 1999). The conflict ensuing from this vote resulted in swift action to curtail the activities of 
women priests. Even today, no parish is bound to accept a woman priest and, as highlighted above, despite much recent campaigning and debate, women still cannot become bishops. As Bagilhole (2006) remarks, this is not so much a glass ceiling like that experienced in secular organizations, but is more akin to a lead roof. Compared with the secular context, therefore, women priests negotiate additional layers of complexity in their occupational lives, especially because religion is invoked as a sacred entity, beyond secular interference (Butt et al., 2004), endorsed through religious exemptions from gender equality legislation. As Stewart-Thomas (2010, p. 409) highlights, unlike secular organizations which express gender neutrality at least in principle, 'many religions do not profess to be gender neutral'. This context impacts on how clothing regimes are negotiated.

This article will examine how clothing has been a vehicle for women's exclusion, as well as acceptance in the Church, based on data generated from seventeen Anglican clergy women. The first data theme will highlight how participants were encouraged to display a 'neutral' body. The second theme considers the sacred spaces that participants navigated. Unlike women in other professions, priests are required to exert sacred, as well as professional authority, and it here that the most hostile reactions to women's clothing can occur. Finally attention will be given to the way in which participants had to navigate clothing that has been designed for male bodies. Firstly, however, the article will be situated in relation to the literature on clerical and occupational dress, followed by a brief methodological account of the research.

\section{Understanding contemporary clothing regimes}

Ordination confers upon individuals new rights in relation to ecclesiastical dress. Three Orders of ordination exist in the Church: deacon, priest and bishop. Individuals are firstly ordained as deacons, a probationary role (normally lasting a year), after which ordination to priesthood takes place. Deacons (see Glossary for explanations of all ecclesiastical terms) enact a number of roles connected with priesthood, but cannot preside at communion, bless or absolve sins (Thorne, 2000). Each level of ordination allows access to different garments, so whereas ordination to the diaconate enables one to wear the clerical collar (colloquially known as the "dog collar"), only those ordained to priesthood can wear a chasuble, and only bishops can wear mitres. 
Therefore, status and prestige are bound up with particular items that hold not only professional significance but also sacred status.

The history of ecclesiastical dress is complex, but the dress worn is not static and unchanging (Renne, 2010). Two dimensions to clergy dress need to be highlighted - firstly, its links to professionalism, and secondly its links to sacrality. After the establishment of the Church of England, clergy 'wore ordinary dress during the week but did reserve special garments, inherited from the Church of Henry VIII... for services and special occasions' (Mayo, 1984, p. 77). Therefore, different attire was appropriate depending on whether it was a worshipping day or not, and many clergy adopted the clothing typical of their professional contemporaries in non-worshipping contexts. Indeed, at this time, clergy had a key role to play in professional activities such as education, but by the $19^{\text {th }}$ century, such tasks were increasingly being catered for by new state-centred providers (Russell, 1980). Clergy felt threatened not only in a professional sense, but also in a sacred sense, for the Church's dominance was being challenged by other religious groups such as Non-conformists. Many wanted to unify clerical dress in order to express the distinctiveness of Church of England clergy, especially in emphasising its status as England's established church (Mayo, 1984), and a vocal minority campaigned for the re-establishment of clerical dress associated with the pre-Reformation Catholic church. This had been strongly discouraged before, because it was too visually close to Catholic dress, from which the new Church of England was trying to disassociate itself. After much contestation, the classic attire of cassocks, surplices and mitres were endorsed and popularized by clergy, although Evangelicals within the Church rejected the new styles for their association with Catholicism, and for creating unnecessary hierarchies between lay and ordained individuals (Mayo, 1984; Renne, 2010). New clothing regimes were nevertheless implemented not only in the worshipping space, but also in everyday contexts, so that clergy had a distinctive style of dress in both professional and sacred spheres. This was aided through the creation of the clerical collar in the early twentieth century, which became a trademark of priesthood. Clothing was therefore demarcated along two strands of signification - one's professional identity (denoted by clerical wear such as the clerical collar, clerical shirt and cassock) and one's sacred identity (denoted by vesture used largely in worship situations such as the chasuble worn during Eucharistic worship). 
Women were excluded from this history of clerical dress. Women were permitted to be deaconesses from 1861, but this was not seen as an ordained role (Aldridge, 1987). In 1987, women were admitted to the Order of Deacon. This meant that for the first time, women had a place in Holy Orders and new clothing regimes had to be negotiated, such as the clerical collar and shirt. However, when the legislative integration of women as deacons was discussed, this provoked much debate within the Church. Some argued that women should retain the colour associated with the deaconess order - blue, rather than clerical black. There was also a call for women to show restraint in wearing the clerical collar (Aldridge, 1987). These controversies were centred upon growing unease about women's admission to a historically all-male role. Women were encouraged to retain their distinctive blue dress which endorsed traditional (and familiar) markers of feminine service, blue being the colour associated with the long-suffering Virgin Mary (Warner, 1978).

The attempts to regulate women's dress in the Church were not successful; the general public would begin to see women wearing the clerical shirt and collar (Walsh, 2001), which started a process of acculturating the public to women's association with professional clerical dress. By 1994, and admission to the Order of Priesthood, the attire of priests became fully available to women (for example, wearing the chasuble for Eucharistic worship, and the wearing of the stole over both shoulders).

Clothing is therefore crucial to one's occupational identity as a priest. On ordination, access is granted to garments that lay people have no legitimate claim to. As priesthood has historically been constituted through the embodied male, women can find that their clothing choices come under increased scrutiny and can be used as a determinant of whether women can convincingly enact a professional and sacred identity. Clothing thus embeds the priest into the occupational structures of the Church, yet women's negotiation of these occupational structures is hampered by the masculinist tradition underpinning the organization. As Acker (1990, p. 142) has theorized, 'gender is difficult to see when only the masculine is present', and the inclusion of women's bodies can constitute these bodies as problematic. A number of studies (e. g. Brewis and Sinclair, 2000; Entwistle, 2000; Puwar, 2004) have emphasized that certain bodies can be deemed 'out of place’ (Puwar, 2004, p. 8) in secular organizations such as businesses and parliament, when processes, roles and even architecture can militate against women’s inclusion. For example, women managers may be assumed to be secretaries; the space of Westminster is structured 
around the norms of a gentleman's club; one's behaviour at Prime Minister's Question Time is predicated on an aggressive debating style that is more commonly deemed to be successfully enacted by men. Such research has also emphasized the particular role clothing plays in gendering the organization. Studies of dress at work have put much focus on the extent to which individuals embody the norms of the organization through their attire. The question that is often raised is whether women in male-dominated spheres endorse masculine dress codes. Puwar's (2004) study of MPs in the House of Commons highlights that women's bodies are highly visible and clothing styles, hair and make-up are all ripe areas for critique and ridicule. This can encourage conservative styles of clothing that align with male styles of dress. Van den Brink and Stobbe (2009) emphasize that women scientists are encouraged to blend in with male dress codes. Women therefore eschew make-up and feminine attire. Meanwhile, Entwistle (2000) examines how power dressing was popularized by professional women from the 1970s onwards, with women wearing suits enhanced by the odd marker of femininity, such as a scarf. Similarly, Sheppard's (1989, p. 145) study of Canadian managers highlighted that women were under 'constant vigilance regarding gender (and sexual) self-presentation'. There is all at once the pressure to conform to a professional and business-like aesthetic, through utilising sombre colours and tailored suits that reference male styles of dress, whilst at the same time also trying to retain some element of femininity. But women are encouraged to be vigilant against clothing that is encoded as sexually suggestive, such as low-cut tops and mini-skirts (Nencel, 2010; Rafaeli et al., 1997). Gherardi (1995) highlights that one strategy utilized by women managers in her study was to opt for mid-length hair, as it steered a middle course between long hair which is deemed to denote sexiness, and short hair which is encoded as masculine. Women in the workplace are therefore expected to navigate a very narrow tightrope which all at once presents a self that is not overly masculine or feminine.

Much less work has been undertaken in understanding the role clothing plays in occupational spaces underpinned by sacred, as well as professional, values. Drawing on this body of literature, this article will go on to examine how ordained women negotiated church clothing regimes, in an occupational space where masculinist norms and traditions have been embedded for centuries.

\section{Methodology}


This article emerges from a wider project that mapped gender identities in the Church of England, most notably, clergy mothers, as well as male clergy spouses. In this article specific attention is given to the women's negotiations of clothing regimes in their occupational context. The study sought to obtain in-depth accounts of the experiences of women in terms of their workplace and home-life negotiation, with interviews conducted between 2006 and 2007. Participants were recruited through gate keepers within the Church of England, such as diocesan officials. In total, 17 women were interviewed - 15 were priests and two were deacons. The women were diversely located throughout England, and were at various stages of their career. Some had recently entered the Church, others were in senior posts. Meanwhile, others held middle management positions. The age range of the women was 31 to 54 . All were white. All but one was in stipendiary (paid) church roles, and all women had children. The participants have been given pseudonyms.

The interviews aimed to generate rich accounts, and each interview started with the question, 'Tell me how you came to be a priest'. An interview guide was used as a loose prompt, containing a core section covering occupational issues such as the church and gender, whether participants had experienced gender stereotypes, personal meanings of priesthood, and clothing. Some raised the issue of clothing spontaneously, but in cases where clergy were prompted to discuss issues around clothing, many participants became animated, with the women having specific stories to tell. The data gathered was therefore created in a particular context, and as a researcher, I did not start with a view from nowhere, for a frame had been placed around the interview. Principally, gender was the theme underpinning my interest. Therefore, the accounts were produced in a particular context, and there was no expectation that 'truths' were being located and found. Rather, the data produced a particular type of knowledge in a given situation (Ramazanoglu, 2002). All interviews were at least an hour in length, with some lasting over two hours. The interview transcripts were later thematically analysed, and as a topic on the agenda, clothing became a salient area for exploration. Thematic analysis is a form of narrative analysis where the content of what is said is prioritized, and organized alongside stories with similar themes. As Riessman (2005, p. 2) articulates, stories are gathered and researchers 'inductively create conceptual groupings from the data', and it is useful in mapping common experiences into themes. The numbers interviewed were 
small, but the rich accounts gathered from the in-depth inquiry undertaken gave detailed insights into the negotiation of clothing. Although this study does not claim to be representative, it illuminates some pertinent themes regarding how this particular group of women were occupationally integrated in relation to occupational dress.

\section{Confused roles and the neutralization of women's bodies}

Participants had entered the Church as ordained clergy at different points in time, but some had been part of the first cohort of women ordained into Holy Orders. Once the legislation had been ratified allowing women's ordination to the diaconate, women duly started to be ordained as deacons in 1987. However, between 1987 and 1994 women were allowed to become deacons, but not priests. This period has been termed the 'long diaconate' (Francis and Robbins, 1999) for although men during this time would be ordained priest after one year, women remained deacons. As Bagilhole (2002, p. 72) wryly remarks, being a deacon was a 'one year probationary period for men, but for women it was envisaged to be the height of their career'. In the lay consciousness, confusion abounded, as many did not understand whether women were actually priests or not, precipitated by the fact that women were now allowed to wear the clerical collar (Aldridge, 1987). As such this first generation of women deacons experienced an anomalous status (Aldridge, 1989). People would see women preaching and officiating at funerals, for example, so assumptions were made that women were priests. Indeed, Laura, a 43 year old chaplain, articulated how, during this period of the 'long diaconate', people would stop her in the street if she was wearing her clerical collar, with questions asked over whether she was a 'woman vicar'.

As Keenan (2001a, p. 4) argues, ‘[c]lothes are society’s way of showing where we belong in the order of things, our role and position in the social pageantry', but when clothing regimes change, confusion can result. There is no expectation that lay church members would know or be concerned about the intricate rules and regulations that govern clerical attire, and how this relates to different levels of ordination. Hence, a woman wearing a clerical collar could indeed be interpreted as a priest.

In 1992 approval was given for women to be ordained as priests in the Church of England, with the first ordinations taking place in 1994. On becoming a priest, and 
being accorded new rights and responsibilities associated with that status (e.g. presiding at communion), a number of participants experienced scrutiny of their clothing choices, both from parishioners and fellow male clergy. In some instances, this was connected with women subverting the traditional masculine attire. Lois, a 31 year old curate, discussed how fellow clergy would appraise her attire when attending church meetings:

And your dress will be commented on. I've got one or two dog collar shirts that are patterned, and I always team them with something plain but they're just more relaxed things and they always get commented on. You are treated like you're there... on sufferance.

Lois's subtle altering of a masculine dress code with a more feminine style was contemptuously appraised; women's professional presentation was held up for critical examination. Despite colourful shirts becoming more popular since women became ordained (Peyton and Gatrell, 2013), in Lois's case, there was still unease that this tampered with well-worn masculinist traditions. It was not only in professional contexts that such scrutiny occurred. In the worshipping space, too, participants had encountered negative reactions, particularly to jewellery. Eleanor, a 43 year old curate, arrived as a new priest at a church where a parishioner had refused to receive communion from a woman for many years. However, in Eleanor's case, the parishioner made an exception, because Eleanor did not wear earrings - in this parishioner's mind, dangly earrings personified what was most objectionable about women becoming priests.

Esther, a 50-year old parish priest, led a service at a Methodist chapel one Sunday, and was therefore not required to robe in the same way that she would be expected to for an Anglican service. Instead, she wore smart 'lay' clothes:

I went to preach a sermon in a Methodist chapel... and I had a plain blue dress and a blue jacket and a little white brooch. Plain but smart. You know, I'm not fancy and flowery anyway. And one lady said to me after the sermon, I was very distracted by your brooch. Which was only tiny, you know I don’t do big, showy stuff and I thought if she was really, then there's an argument for cassock-albs with something plain and simple that covers up whatever you are. 
This element of feminine embodiment (the discreet brooch) was scrutinized. Similar to the parishioner abhorrence toward earrings, there was an unwillingness to incorporate any element of feminine adornment for being 'distracting'. These accounts expressed an aversion to the feminine. Using Entwistle’s (2000, p. 8) terminology, Lois and Esther had 'disruptive' bodies, contravening expected codes. A male norm was sought, and feminine adornments such as jewellery were seen as unsuited to the sacred role. Butt et al. (2004) document that the wearing of nail polish and high heels by women priests has been frowned upon, with these markers of femininity being seen as at odds not only with the professional self, but also the sacred self. This adds another layer of complexity to participants' experiences, for not only were they navigating a masculine culture, typically found in secular spaces - but they were also responsible for demonstrating a sacred display. And as sacrality has been more thoroughly associated with men (Bock, 1967; Northup, 1997), feminine attire took on a profane status - the 'distraction' in the worshipping space. Such reactions may also link to the prevailing association between women's bodies and sexuality. Historically, earrings have denoted a lack of respectability, especially connected with overtly sexual women (Entwistle, 2000; Ward, 2010). Within a Christian discourse, Jezebel, the Old Testament princess, holds extremely negative connotations - a woman who is abhorred for her exuberant, excessive style and linked with prostitution (Tseëlon, 1995). Because women's bodies have been constructed as being representative of the sexual (in a way that male bodies have not), when they enter 'male' spaces, particularly the workplace, there is a pressure on women to 'neutralize’ their bodies (Furlong, 1984; Tseëlon, 1995). As Acker (1990, p. 142) puts it, 'Since men in organizations take their behavior and perspectives to represent the human, organizational structures and processes are theorized as gender neutral'. Women’s bodies 'contaminate’ (Acker, 1990, p. 142) this space, by clashing with the surrounding male culture, which is assumed to be gender neutral. Women have to manage their bodies by being as inconspicuous as possible, and downplaying any sexual signification. As Van den Brink and Stobbe (2009) articulate, in an occupational context of perceived asexuality, women's bodies come to represent a visible sexuality. Conforming to male gender regimes can afford women the opportunity to fit in. 
Indeed, some women sought out attire that would downplay femininity. Robes could be endorsed by participants in order to achieve sacred authority:

Robes for me cover up... a cassock-alb which is just white, for me, is all that's required because it covers you up and stops you having to make yourself into a fashion parade. (Jill, 51, senior post holder)

This can be interpreted as evidence of a masculinized norm reigning triumphant, with women's bodies concealed under the weight of tradition so that they could almost be men. As Peyton and Gatrell (2013, p. 96) argue, androgynous robes achieve a 'visible invisibility' - women are all at once visible and invisible. Jill wished to embody neutrality and safety, adopting only one colour and removing any feminized elements. She was also quite clear that she wanted to avoid the demanding 'fashion parade' that women are implicated in, and this also revealed tensions in self-presentation, for fashion itself has been deemed frivolous and trivial (Entwistle, 2000; Niessen and Brydon, 1998). It is women who are predominantly associated with fashion, with women called upon to represent the fashionable in a way that men do not (Entwistle, 2000; Tseëlon, 1995), but this has radical implications in discrediting women’s affinity with public office. As Parkins (2002) outlines, women’s association with fashion has deemed them inappropriate for political roles, for the political body is conceived in terms of maturity and seriousness - everything fashion is not. Like political dress, church attire too has divorced itself from 'frivolous' fashion, for sacred dress is constituted as beyond fashion (Keenan, 2006) - and in so doing, is disassociated from the profane world, and established as part of the sacred realm. Fashion can therefore be dangerous territory for women cultivating particular public and sacred roles, and this is one reason why women's dress is scrutinized in a way that men's dress is not.

This attempt at presenting a gender-neutral display could be double-edged and could impact on whether women were considered 'feminine' enough. For example, Rachel, a chaplain, called her style 'conservative'; she adopted a traditional black shirt with a white clerical collar. Carroll et al. (1981) argue that clerical dress is a symbol of status. It indicates respectability, credibility, and legitimacy. A clerical collar is often seen as the authority symbol denoting (sacred) placement in the organisation. However, Rachel had been critiqued by family members (including her 
husband) and friends, for being 'boring' in her style. The lack of bright colours and associated adornments of femininity brought into question Rachel's success in portraying herself as a woman. Participants were therefore critiqued if they dressed like men, and also if they utilized feminine apparel. Although some women priests may have taken on the emblems of a male priesthood in an androgynous display, this did not necessarily legitimize the choice of others to present as feminine women, for sacred authority positions have not been constituted in this way.

\section{Negotiating sacred space}

The previous section highlighted that participants were strongly encouraged to foreground a 'neutral' display in both professional and sacred contexts (even though the basis of this so-called neutrality can be questioned). But it was in the sacred worshipping space that most negativity about women's attire seemed to be generated. Stephanie was an area dean and was required to attend the ordination service of a member of her team. However, this occurred in a church which was opposed to women's ordination. As she narrates, 'I went to the new licensing in a Forward in Faith church, and I went robed, and I caused such a row that all the other clergy that had come walked out... Seeing a woman robed was so offensive'.

As Keenan (1999) articulates, sacrality is represented through clothing choice. Women's vesture in robes embodies the sacrality of the priestly role, considered by some as too sacred a space for women (Aldridge, 1992; Furlong, 1991; Tseëlon, 1995), thus disrupting a historical legacy where men were given exclusive access to these garments. This becomes even more pertinent as sacred vestments tend to be feminine in style, consolidated through, for example, the use of elaborate embroidery (Stringer, 2000). The reaction to Stephanie in clerical robes manifested great anxiety around border-crossing. Not only was she entering a masculinized sacred space, she was doing so through a particular clothing style which drew attention to the wider coding of vestments as feminine in style and thus disrupted men's exclusive link to the sacred.

Many clerical garments have their origins in classical Greek dress (Norris, 1949), but in contemporary contexts, some garments such as cassocks can be seen as emasculating. Dawn, a 38 year old parish priest, commented that, 'the things that the priests wear... they're dresses'. In addition, many items of clothing used in worship 
are also ornate and decorated in embroidery, further cementing a link with feminine attire (Blohm, 2005; Mayo, 1984; Stringer, 2000). While men in feminized attire are usually ridiculed, in some spaces (e.g. the judiciary and church), such attire has cemented and solidified male power, based on the traditional exclusion of women's bodies. However, while judges have kept the colours of their robes sombre in colour and design, certain sections of the Church of England have embraced elaborate styles (Stringer, 2000). Prior to women being priested, there was a clear demarcation between the clothing of (ordained) men and (lay) women, but now that women have equal access (up to the role of priest) it blurs the boundaries, and problematizes the construction of these garments as sacredly masculine, creating greater anxiety in men's self-presentation (Blohm, 2005; Ruether, 1980). The way the clothing terrain is negotiated by men alters with the inclusion of women's bodies.

Participants were very aware that they could encounter negative reactions to their presence in sacred spaces, especially as it was here that priests could encounter parishioner refusal in receiving communion from them (Blohm, 2005; Dyer, 1999; Jones, 2004; Page, 2010). In this context, it was revealing that priests often put churchgoers and their audiences at the centre of their decision-making over what they wore in the worshipping space. Esther made finely-graded distinctions on the basis of her worshipping community, for example, outlining that she only wore a chasuble at Christmas because it was expected of her by the largely non-churchgoing public in attendance. Although regular congregants did not want/expect ritually elaborate clothing displays, the nominal churchgoers arriving for the Christmas service expected something special and colourful, and Esther obliged. Although this may not on the surface be a specifically gendered negotiation, the act is significant for it highlights Esther's compliance with audience demands, endorsing notions of feminine service and putting others first.

Jill also emphasized that she was prepared to subvert her own preferences for the benefit of others:

If I'm in an ordinary parish somewhere and whatever their tradition is I will follow. So if they [parish priest] wear a cassock-alb and a stole, I wear a cassock-alb and a stole. If they wear a cassock and a stole but a chasuble over the top of it, I will put a chasuble over the top of it. 
Therefore an altruistic display comes through in these accounts, where clothing choice is made for the benefit of worshippers, thus subduing participants' own predilections. This emphasizes the wider significance of altruism and service, values that priests are expected to embody (Peyton and Gatrell, 2013; Russell, 1980). However, it also points to a specific gendered dimension where women priests have experienced much negativity to their presence in sacred space (Page, 2012), and it is significant that many participants prioritized the appeasement of congregants, which may be linked to the wider aversion the women had encountered in sacred contexts.

\section{Negotiating the attire of men}

Women often had to negotiate practical difficulties in relation to their clothing, especially due to its design. This attire had been designed for men. As the previous sections have outlined, the participants had to present themselves in accordance with the 'correct' professional and sacred display. But they also had to contemplate whether these clothes historically designed for men actually suited them. Many women found the robes too big for them. Kate’s place of work had recently updated their vestments, but had not done this with reference to women, and all of the vestments were too large. Lois explained the indignity involved in this: 'when they're too big for you, you're likely to knock things over with them and they're nearly dragging on the floor'. This indicates something fundamental about women's integration into the Church. If women are not given clothes that properly fit, symbolically, it says that women are unable to fill the shoes of men, and participate in the sacred role convincingly. It can also be seen as a way in which (male) authorities ensure clothing is kept as a male terrain, endorsing the organization as a masculinist space.

Organizations use clothing as a means of institutional control. Utilizing some form of uniform consolidates this power (Fineman, 2003), and this can have particular gendered effects. Entwistle (2000) has argued that the body is brought into being through clothing; certain clothing styles emphasize gendered difference, such as the way a jacket emphasizes a man's broad shoulders; a woman's neckline emphasizes her breasts. This can be cultivated by organizations in retaining control of women's bodies. Young's (1992) study of the integration of women into police uniform regimes highlights how policewomen were for many years instructed to wear skirts 
even though this was very impractical in their work. Similarly, Gaines (1990) offers fascinating insights regarding how Hollywood cultivates the currently acceptable female form through clothing, even when working with actresses who fall short of the 'ideal'. Seams and hems reworked, designers can do anything from de-emphasising breasts and buttocks, to making actresses appear shorter. These examples illustrate the ways in which institutions culturally produce their clothing regimes for particular effect. Meanwhile, in the Church, failing to alter clothing can have negative outcomes, as Boyce-Tillman (2010, p. 32) narrates - a priest who argues that clerical garments are generally made 'for bodies that had shoulders wider than hips... The cassock and surplice were the worst for not only did the cassock fall off at the shoulders but the surplice... [was] designed for someone at least a foot taller than me'. The cassock and surplice combined with the male body embodied a 'natural' fit, giving the mistaken assumption that this was innate rather than culturally produced. Women's negotiation thus becomes more complex as they assert themselves in spaces where garments worn do not enhance their best features; meanwhile for men, their vesturing is assumed and automatic, buttressed through historical convention.

It is hugely significant that a number of priests had difficulties with garments that did not fit correctly. Maintaining a closet of robes too big for women disrupts women's sacred claim to these garments. Contrast the experiences of priests contending with oversized garments with that of Dawn, who could not praise her church more highly for the way in which they integrated her as a priest:

[I had a] lovely experience in Smalltown... all their vestments swamped me. They actually got vestments made for me that actually fitted me and they were given as a gift when I was ordained, which felt... very affirming. You know, they actually got a woman's chasuble... it was a nice one as well.

Symbolically, Dawn had been accepted into her community by the way in which they had made sure the vestments of the Church fitted her perfectly. As Keenan (2001b) argues, social control and constraint are embedded in dress regimes so whether superiors ensure vestments fit or not says something powerful about whether women are deemed to be suited to the sacred role.

\section{Conclusion}


Clothing is a salient area for exploration in understanding the gendered nature of inclusion and exclusion in occupational settings, offering another lens through which organizational embodiment can be analysed. The attire of the women priests interviewed was often under scrutiny, with participants having to carefully navigate their gender display. Women's bodies have not traditionally been included in either the professional or sacred attire of priests. Clerical shirts and collars represent professional masculine status. Women's negotiation is therefore fraught for if they assimilate, and don the traditional black, they are seen as subverting their femininity, but if they endorse more feminine patterns and colours, this is seen as discrediting the professional space that is bound up with masculinity. In addition, priests occupy sacred spaces, denoted through special garments that only those ordained can legitimately wear. For those opposed to women's priesthood, however, this can cause outrage, as women are seen as accessing space that does not belong to them.

Participants were engaging in complex clothing negotiations based on a variety of 'audiences' they were presented with - whether colleagues, parishioners or irregular churchgoers (Goffman, 1990). The audience is crucial in understanding the selves that clergy project. As Peyton and Gatrell argue,

Work and embodiment are... linked to the extent to which the work is carried out under the gaze of others... Being called upon to present oneself in particular ways raises questions of gender and the relation between the performance and the audience (Peyton and Gatrell, 2013, p. 95)

Goffman (1990) discusses the audience in terms of those who evaluate and judge the performance of an individual. This is the display of self in the 'front region'. Hence parishioners, viewing the performance of the priest, can be deemed audience members in this Goffmanesque sense. Meanwhile, fellow clergy, as individuals who also have to perform in the front region before audience members, can be deemed colleagues in interaction - they can perform the crucial role of offering a space where one's guard can be dropped, and where relaxation in the role occurs, for 'In having to put on the same kind of performance, they come to know each other's difficulties and points of view; whatever their tongues, they come to speak the same social language' (Goffman, 1990, p. 159). But this camaraderie was not necessarily evident in the ways 
in which fellow (male) priests viewed women priests' attire. Instead, fellow priests as well as parishioners could play a role in scrutinising women's clothing, either affirming or undermining their very presence in the space of the Church.

Ultimately, participants put a great amount of effort in choosing clothes that would appease the various audiences they were negotiating. They prioritized audience expectations, which corresponds with the way in which priests are expected to be altruistic towards others. However, this negotiation was seriously undermined by the way in which, at a very practical level, clothes did not necessarily fit women properly, especially in worshipping contexts where communal robes were utilized. The worshipping space is an interesting arena that signifies not only women's professional incorporation, but also their sacred inclusion. As a space in which debates about women's ordination rights are fiercely contested (as indicated in the experience of the intensely negative reaction to a robed woman at an ordination service), the worshipping space becomes the focal point for women's full acceptance. It is significant that it is here, more so than in relation to professional spaces (and the associated attire) that the ability of women to convincingly enact their roles is most seriously questioned, through the way some worshipping spaces refused to stock generic robes that would fit women. The worshipping space has traditionally been heavily policed as a sacred space, and one where women's bodies have been deemed out of place, lacking the required holy dispositions. For instance, Ruether (1990) has articulated how many Christian churches (Catholic as well as Protestant) have deemed women's bodies as unholy, with women being barred from sanctuary space, with the prevailing idea that women would taint holy objects through their very touch. Women's acceptance in sacred occupations has been deemed more problematic than their secular counterparts, with women's inclusion in the Church of England lagging well behind other professional spheres. To this day, pressure groups still exist with the principal aim of campaigning against women's priesthood.

In a wider context of gender rights, where gender equality is enshrined in law, the Church of England is positioned in an anomalous situation - an organization premised on the idea that all are equal in Christ, but with entrenched gender discriminations written into the very legislation. Indeed, although more sacred clothing options have become available to women as they enact the role of deacon and priest, other garments are still off limits, such as mitres and pectoral crosses, the attire associated with bishops. This lack of inclusion sits alongside more recent attempts by 
the Church to accord more fully with employment rights, as evidenced in the 2011 Clergy Terms of Service Measure, where for the first time, clergy were given rights such as the ability to appeal to an employment tribunal, as well as paternity and maternity entitlements. This complex contextual background problematizes the full acceptance of women in the Church. Examining this through the lens of clothing illuminates the multi-dimensional nature of inclusion and rejection, and the difficult terrain that ordained women navigate.

\section{Acknowledgements}

I thank the ESRC for funding this research (Award numbers PTA-031-2004-00290 and PTA-026-27-2911). I also wish to thank the participants who made the research possible, the anonymous reviewers for their extremely insightful comments and Prof. Andrew Yip and the Rt Rev Dr Nigel Peyton for offering valuable feedback to this paper.

\section{References}

Acker, J. (1990) Hierarchies, jobs, bodies: a theory of gendered organizations. Gender and Society, 4,2, 139-58.

Aldridge, A. (1987) In the absence of the minister: structures of subordination in the role of deaconess in the Church of England. Sociology, 21,3, 377-92.

Aldridge, A. (1989) Men, women, and clergymen: opinion and authority in a sacred organization. The Sociological Review, 37,1, 43-64.

Aldridge, A. (1992) Discourse on women in the clerical profession: the diaconate and language-games in the Church of England. Sociology, 26,1, 45-57.

Bagilhole, B. (2002) Women in Non-Traditional Occupations: Challenging Men. Basingstoke: Palgrave Macmillan.

Bagilhole, B. (2006) Not a glass ceiling more a lead roof: experiences of pioneer women priests in the Church of England. Equal Opportunities International, 25,2, 109-25.

Blohm, U. (2005) Religious Traditions and Personal Stories: Women Working as Priests, Ministers and Rabbis. Frankfurt and Main: Peter Lang.

Bock, E.W. (1967) The female clergy: a case of professional marginality. American Journal of Sociology, 72,5, 531-39.

Boyce-Tillman, J. (2010) Colouring outside the lines. In Slee, N. and Burns, S. (eds) Presiding Like a Woman, pp. 27-37. London: SPCK.

Brewis, J. and Sinclair, J. (2000) Exploring embodiment: women, biology and work. In Hassard, J., Holliday, R. and Willmott, H. (eds) Body and Organization, pp. 192-214. London: Sage.

Butt, C., Threlfall-Holmes, M. and Vasey-Saunders, L. (2004) Women priests: the next generation. Anvil, 21,2, 105-12. 
Carroll, J.W., Hargrove, B. and Lummis, A.T. (1981) Women of the Cloth: A New Opportunity for the Churches. San Francisco: Harper and Row.

Church of England (2011) Church Statistics 2009/10. London: Church House Publishing.

Dowell, S. and Williams, J. (1994) Bread, Wine and Women: The Ordination Debate in the Church of England. London: Virago.

Dyer, A. (1999) Reviewing the reception - five years of women priests. Anvil, 16,2, 85-93.

Entwistle, J. (2000) The Fashioned Body: Fashion, Dress and Modern Social Theory. Cambridge: Polity Press.

Fineman, S. (2003) Understanding Emotion at Work. London: Sage.

Francis, L.J. and Robbins, M. (1999) The Long Diaconate 1987 - 1994. Leominster: Gracewing.

Furlong, M. (1984) Introduction. In Furlong, M. (ed) Feminine in the Church, pp. 110. London: SPCK.

Furlong, M. (1991) A Dangerous Delight: Women and Power in the Church. London: SPCK.

Furlong, M. (1998) Introduction. In Furlong, M. (ed) Act of Synod - Act of Folly? pp. 1-13. London: SCM Press.

Gaines, J. (1990) Introduction. In Gaines, J. and Herzog, C. (eds) Fabrications: Costume and the Female Body, pp. 1-27. London: Routledge.

Gherardi, S. (1995) Gender, Symbolism and Organizational Cultures. London: Sage.

Gill, S. (1994) Women and the Church of England: From the Eighteenth Century to the Present. London: SPCK.

Goffman, E. (1990) The Presentation of Self in Everyday Life. London: Penguin Books.

Jones, I. (2004) Women and Priesthood in the Church of England Ten Years On. London: Church House Publishing.

Keenan, W.J.F. (1999) From friars to fornicators: the eroticization of sacred dress. Fashion Theory, 3,4, 389-410.

Keenan, W.J.F. (2001a) Introduction. In Keenan, W.J.F. (ed) Dressed to Impress: Looking the Part, pp. 1-49. Oxford: Berg.

Keenan, W.J.F. (2001b) Dress freedom: the personal and the political. In Keenan, W.J.F. (ed) Dressed to Impress: Looking the Part, pp. 179-96. Oxford: Berg.

Keenan, W.J.F. (2006) Sacre Bleu: faith, fashion and freedom: Marist foundation garments 1817-1862. In Arweck, E. and Keenan, W.J.F. (eds) Materialising Religion: Expression, Performance and Ritual, pp. 116-137. Aldershot: Ashgate.

Mayo, J. (1984) A History of Ecclesiastical Dress. London: B.T. Batsford Ltd.

Nencel, L. (2010) Que viva la minifalda! Secretaries, miniskirts and daily practices of sexuality in the public sector in Lima. Gender, Work and Organization, 17,1, 69-90.

Niessen, S. and Brydon, A. (1998) Introduction. In Brydon, A. and Niessen, S. (eds) Consuming Fashion: Adorning the Transnational Body, pp. ix-xvii. Oxford: Berg.

Norris, H. (1949) Church Vestments: Their Origin and Development. London: J.M. Dent \& Sons.

Northup, L. A. (1997) Ritualizing Women: Patterns of Spirituality. Cleveland: The Pilgrim Press. 
Page, S. (2010) Femininities and Masculinities in the Church of England. PhD thesis, School of Sociology and Social Policy, Nottingham: University of Nottingham.

Page, S. (2012) Femmes, mères et prêtres dans l'Église d'Angleterre: quels sacerdoces. Travail, Genre et Sociétés, 1,27, 55-71.

Parkins, W. (2002) Introduction: (ad)dressing citizens. In Parkins, W. (ed) Fashioning the Body Politic: Dress, Gender, Citizenship, pp. 1-17. Oxford: Berg.

Peyton, N. and Gatrell, C. (2013) Managing Clergy Lives: Obedience, Sacrifice, Intimacy. London: Bloomsbury T\&T Clark.

Puwar, N. (2004) Space Invaders: Race, Gender and Bodies Out of Place. Oxford: Berg.

Rafaeli, A., Dutton, J., Harquail, C. V., Mackie-Lewis, S. (1997) Navigating by attire: the use of dress by female administrative employees. Academy of Management Journal, 40,1, 9-45.

Ramazanoglu, C. (2002) Feminist Methodology: Challenges and Choices. London: Sage.

Renne, E. P. (2010) Ecclesiastical dress. In Steele, V. (ed) The Berg Companion to Fashion, pp. 236-241. Oxford: Berg.

Riessman, C.K. (2005) Narrative analysis. In Kelly, N., Horrocks, C., Milnes, K., Roberts, B., Robinson, D. (eds) Narrative, Memory and Everyday Life, pp. 1-7. Huddersfield: University of Huddersfield.

Ruether, R.R. (1980) The preacher and the priest: two typologies of ministry and the ordination of women. In Parvey, C.F. (ed) Ordination of Women in Ecumenical Perspective, pp. 67-73. Geneva: World Council of Churches.

Ruether, R.R. (1990) Women's body and blood: the sacred and the impure. In Joseph, A. (ed) Through the Devil's Gateway: Women, Religion and Taboo, pp. 7-21. London: SPCK.

Russell, A. (1980) The Clerical Profession. London: SPCK.

Sheppard, D. (1989) Organizations, power and sexuality: the image and self-image of women managers. In Hearn, J., Sheppard, D. L., Tancred-Sheriff, P., Burrell, G. (eds) The Sexuality of Organization, pp. 139-157. London: Sage.

Stewart-Thomas, M. (2010) Gendered congregations, gendered service. Gender, Work and Organization, 17,4, 406-432.

Stringer, M. (2000) Of gin and lace: sexuality, liturgy and identity among AngloCatholics in the mid-twentieth century. Theology and Sexuality, 7,13, 35-54.

Thorne, H. (2000) Journey to Priesthood: An In-depth Study of the First Women Priests in the Church of England. Bristol: Centre for Comparative Studies in Religion and Gender.

Tseëlon, E. (1995) The Masque of Femininity: The Presentation of Woman in Everyday Life. London: Sage.

Van den Brink, M. and Stobbe, L. (2009) Doing gender in academic education: the paradox of visibility. Gender, Work and Organization, 16,4, 451-70.

Walsh, C. (2000) Speaking in different tongues? A case study of women priests in the Church of England. Sheffield Hallam Working Papers on the Web. Available at: http://extra.shu.ac.uk/wpw/femprac/walsh.htm [Accessed 26.04.13].

Walsh, C. (2001) Gender and Discourse: Language and Power in Politics, the Church and Organisations. Harlow: Longman.

Ward, S. (2010) Earrings. In Steele, V. (ed) The Berg Companion to Fashion, pp. 232-36. Oxford: Berg.

Warner, M. (1978) Alone of All Her Sex: The Myth and the Cult of the Virgin Mary. London: Quartet Books. 
Webster, M. (1994) A New Strength, A New Song: Journey to Women's Priesthood. London: Mowbray.

Young, M. (1992) Dress and modes of address: structural forms for policewomen. In Barnes, R and Eicher, J. B. (eds) Dress and Gender: Making and Meaning in Cultural Contexts, pp. 266-85. Oxford: Berg.

\section{Appendix: Glossary of Ecclesiastical Terms}

Alb: a white tunic usually worn over the cassock.

Area Dean: a middle-management position, where a priest has pastoral responsibility for other clergy in their geographical area.

Cassock: a tunic worn either alone or underneath Eucharistic vestments.

Cassock-alb: a garment developed in the last thirty years that combines the features of a cassock and an alb to create a more tailored fit.

Chaplain: works occupationally outside of the Church of England in secular settings such as universities and hospitals (although many are still involved in worship provision at Sunday services within the Church).

Chasuble: an ornate garment, semi-circular in design, used in Eucharistic worship.

Curate: someone in a training position immediately following ordination, where priests work with more experienced colleagues.

Deacon: one of the three Holy Orders, an individual is ordained as a deacon before proceeding to ordination to priesthood, usually a year later. The third Holy Order is that of Bishop. Women started to be ordained as deacons in 1987 and as priests in 1994. They are still not allowed to be ordained as bishops in the Church of England.

Deaconess: a lay ministry role, occupied only by women. The movement started in 1861 but was closed to new entrants after women were allowed entry to the diaconate, alongside men, in 1987.

Forward in Faith: a conservative Anglo-Catholic group. They campaign against women's ordination.

Mitre: a conical cap worn by a bishop.

Parish priest: an ordained person who is in charge of a parish church.

Pectoral cross: a sizeable cross worn on a long chain by bishops around the neck.

Robe: a general term, meaning to put on vestments for worship.

Senior post holder: being used here to describe roles above the parish, e.g. at a diocesan or cathedral-level setting. Women in such posts are in a minority; hence specific post titles are not specified in order to protect identities.

Stole: a long narrow scarf that when placed around the neck, hangs down on each side of the wearer. Deacons wear the stole too, but only over one shoulder.

Surplice: worn over the cassock, and is white in colour. Vergers, choristers and servers also wear the surplice.

Team vicar: works as part of a team in large churches, or in order to cover a number of churches.

Vestments: garments usually worn by clergy during worship. 